\title{
Student independence in overcoming the impact of covid-19: classical online guidance based on character values
}

\author{
Hera Heru Sri Suryanti*, Sri Hartini, Ferisa Prasetyaning Utami \\ Universitas Slamet Riyadi \\ *Corresponding Author: heraherusrisuryanti@unisri.ac.id
}

\begin{abstract}
Independence is an individual's ability to face, accept, and find solutions to solve problems without harming/incriminating other parties. The purpose of the study is to increase student independence in solving the problem of the impact of COVID-19 through online classical guidance based on character values. This research is experimental with a one-group pre-test-post-test experimental design. The research population was 190 FKIP students in Solo Raya. 48 samples were determined using purposive sampling, 20 students were selected from samples with low levels of independence. Data collection using self-reliance instrument questionnaires, observation, interviews, and documentation. Data analysis used non-parametric statistics with the Wilcoxon Signed Rank Test. The results showed that there was a significant difference in the pretest and post-test scores of students' independence in overcoming the problem of the impact of COVID-19 obtained from the results of the Wilcoxon Signed Rank test, namely the value $(\mathrm{p}=0.000)<0.05$, which means online classical guidance is based on character values. can increase student independence by overcoming problems with the impact of COVID-19.
\end{abstract}

Keywords: student independence, the impact of COVID-19, classical online guidance, character values

\begin{tabular}{|c|c|c|c|}
\hline \multicolumn{4}{|l|}{ Article history } \\
\hline $\begin{array}{l}\text { Received: } \\
15 \text { November } 2021\end{array}$ & $\begin{array}{l}\text { Revised: } \\
19 \text { December } 2021\end{array}$ & $\begin{array}{l}\text { Accepted: } \\
7 \text { February } 2022\end{array}$ & $\begin{array}{l}\text { Published: } \\
\text { 14 February } 2022\end{array}$ \\
\hline
\end{tabular}

\section{INTRODUCTION}

Independence is one of the important abilities that must be possessed by students. Independence is the capital to achieving the ideals of student life. The independence in question includes the ability to overcome various problems of life without depending on others. To overcome these problems, students need knowledge, attitudes, and skills.

Independent students have the characteristics of being able to use existing opportunities positively and productively. Therefore, it is necessary to provide educational practices for sustainability-related educational guidance services for their skills development (Poza-Vilches et al., 2019). In addition, these activities can increase creativity, problem-solving, leadership, communication, and innovation (Escolar-Llamazares et al., 2019). Educational programs for students use multifaceted interventions to improve future knowledge, skills, and attitudes, as well as critical thinking (Kim et al., 2019).

The role of classical guidance in higher education should be clarified. The application of guidance and counseling services in tertiary institutions, especially classical guidance, has the aim of forming and increasing life independence, which is marked by the achievement of students' abilities to deal with and solve life problems due to the impact of COVID-19. In implementing classical guidance services, counselors need to have a basic attitude oriented towards attitude. The counselor 
is expected to have an attitude that can raise the awareness and willingness of the counselee to be actively involved in the counseling process (Ganciu \& Ganciu, 2014; Setiyowati, 2019). Complex interactions in interpersonal relationships need to be improved (Lopez-Carmona \& Paricio Garcia, 2021). The independence of students in overcoming the problem of the impact of COVID-19 needs to be improved. Problems that arise as a result of COVID-19 include personal problems, social problems, academic problems, and career problems. Social problems include roles as family members and roles as community members. Academic problems include academic problems. Career problems include work problems. Personal problems consist of economic problems and adjustment problems as well as serious problems such as anxiety and depression (Kürşat et al., 2020).

Students are mature adults who should be able to regulate their emotions when dealing with and overcoming problems. This study recommends that counselors adopt appropriate therapeutic techniques aimed at increasing the emotional involvement of all students to increase their chances of doing better. (Wara et al., 2018). Implementation of therapeutic techniques that aim to regulate emotions can be done through live sessions for training new skills, online counseling sessions related to anxiety and stress, providing online guides for exercises and meditation, as well as specialized training. Gonzaga-López et al., 2020; Chanana \& Sangeeta, 2020).

The role of character values in shaping the personalities of students The character values used in this study are religious values, discipline values, and responsibility values. Student personalities are shaped by internal and external factors. Internal factors are innate from birth, and external factors are those of the student environment. Religious character, discipline, and responsibility are character values that can shape the student's personality through obedience to norms. These norms include moral norms, social norms, religious norms, and legal norms. If they obey these norms, students will have good personalities.

The above is in line with the purpose of the counseling and guidance programs in higher education, namely student self-development through the cultivation of character values in the personal, social, learning, and career fields. Especially in universities, it is necessary to provide classical guidance based on character values to develop the character of student independence to overcome the problem of the impact of COVID 19.

However, the reality on the ground is not like the above. There are still students who are not independent and have not been able to use the opportunities that exist positively and productively. Based on a preliminary study conducted on 100 students at Slamet Riyadi University by sending an online independence instrument, it shows that $60 \%$ of students are easily influenced by other people's opinions to solve problems, and 55\% of students are still less confident in making decisions. This can be interpreted to mean that there are still many students who have not been able to show independence in solving the problems they face.

Based on the results of counseling interviews conducted during the odd semester of 2020 at the Guidance and Counseling Technical Service Unit, it was found that 4 campus activist students had not been able to overcome personal problems due to the impact of COVID 19, thus disrupting all their activities on campus and students losing motivation. These personal problems are related to the economy and adjustment. His parents were laid off (termination of employment) and lost their permanent livelihood, so they had to change their lifestyle to adapt to economic conditions.

The role of classical guidance in higher education should not be maximized. This is the result of a personal work evaluation as the Head of the UPTBK (Guidance and Counseling Technical Service Unit). This is due to a lack of manpower in the field and time for implementation. The program in the Guidance and Counseling Engineering Implementation Unit is too broad, so there is not enough time for the implementation of classical guidance. The implementation of classical guidance that is not optimal has an impact on the achievement of goals. Due to the impact of COVID 19 , the initial goal of online classical guidance based on character values is to convey knowledge related to solving life problems. 
The independence of students in overcoming the problem of the impact of COVID-19 is still low. Based on the results of counseling interviews at UPTBK during the even semester of 2020, most of the students who consulted had feelings of boredom and gave up on their academic and career problems. The student attends online lectures using the Microsoft Team program just to cancel the obligation. The reduction of working hours, which has an impact on salaries, makes students who are already working become unmotivated to work.

Based on the results of observations made in the odd semester of 2020 in online lectures, students still consider character values to be less important. This is shown by the behavior of students who attend lectures and are often late in entering the Microsoft Team for reasons such as running out of credit, broken networks, or difficulty entering the Microsoft Team because of their regional position. Based on the results of counseling interviews, there are campus activist students who often violate religious norms, namely not being disciplined in worship. This makes students uneasy and unable to overcome the problems caused by the impact of COVID-19. The data above shows that the values of religious character, discipline, and responsibility have not been maximal in shaping the student's personality.

The novelty of this research lies in the aspect of implementing classical online guidance based on character values. The implementation of classical guidance that has been carried out by guidance and counseling lecturers is offline and problem-based classical guidance. Research on existing character values, among others, examines the integrated e-module with character values that can develop honesty (Sitorus, 2019). In addition, studies on the formation of character values through art for children (Pamungkas, 2021) Another study is about the importance of self-regulation during online learning (Kizilcec \& Mar, 2017), and online learning activities are considered more effective and efficient (Joia, 2021; Pei \& Wu, 2019). To overcome the problems above, it is necessary to research increasing independence in solving the problem of the impact of COVID-19 through online classical guidance based on character values.

\section{METHOD}

This research is classified as quantitative research. The type of experimental research is the one-group pre-test-post-test experimental design (Cohen, 2007). Through this design, the research was carried out in only one experimental group by taking two measurements, namely O1 (pretest) for the initial condition of the student's level of independence to overcome the problem of the impact of COVID-19 before being given treatment. The second measurement of $\mathrm{O} 2$ (posttest) was carried out to measure the final condition of the student's level of independence after being given treatment. The difference between the pretest and the posttest is assumed to be the effect of the treatment given. The research design can be described as follows.

$$
\begin{array}{ccc}
\text { Pretest } & \text { Treatment (Dependent variable) } & \text { Posttest } \\
\mathrm{O}_{1} & \mathrm{X} & \mathrm{O}_{2}
\end{array}
$$

The One Group Pretest and Posttest (Cohen, 2007)

To clarify the picture above, the steps for implementing the research are presented as follows:

1. O1: A pretest was conducted to measure the dependent variable (student independence in overcoming the impact of COVID-19) before treatment (implementation of online classical guidance based on character values) was given.

2. $\mathrm{X}$ : The treatment given is classical guidance based on character values. This guidance is given to see the role of classical guidance based on character values in increasing student independence in overcoming the problem of the impact of covid 19. In this study, the 
treatment was carried out for eight meetings in each service area (Personal, Social, Academic, and Career) and each meeting lasted 60 minutes.

3. O2: A post-test was conducted to measure the dependent variable (student independence in overcoming the impact of COVID-19) after treatment (online classical guidance services based on character values).

The population in this study was 190 students of the Faculty of Teacher Training and Education in Solo-Raya. The research sample of 48 students was taken using the purposive sampling technique. From the number of samples, 20 students who had the lowest score obtained from the independence instrument were taken and used as research subjects to get treatment. The data collection technique used an instrument questionnaire on the level of student independence, observations to see the psychological condition of students with problems, interviews to convey the task of making diaries and to find out the difficulties, and documentation to see the results of student notes. The data analysis technique uses non-parametric statistics with the Wilcoxon Signed Rank Test.

\section{FINDING AND DISCUSSION Finding}

This study was focused on increasing the level of student independence by providing treatment in the form of online classical guidance services based on character values.

Initial Profile of Student Independence in Overcoming the Problems of the Impact of COVID-19

Based on the initial data collection by providing an instrument questionnaire on the level of independence, the student independence profile was obtained with a low category of $11 \%$, a medium category of $75 \%$, and a high category of $14 \%$. The details are presented in table 1 .

Table 1. Description of the Initial Profile of Student Independence in Overcoming the Impact of COVID-19.

\begin{tabular}{ccc}
\hline Category & N & Percentage (\%) \\
\hline High & 27 & 14 \\
Medium & 143 & 75 \\
Low & 20 & 11 \\
\hline TOTAL & $\mathbf{1 9 0}$ & $\mathbf{1 0 0}$ \\
\hline
\end{tabular}

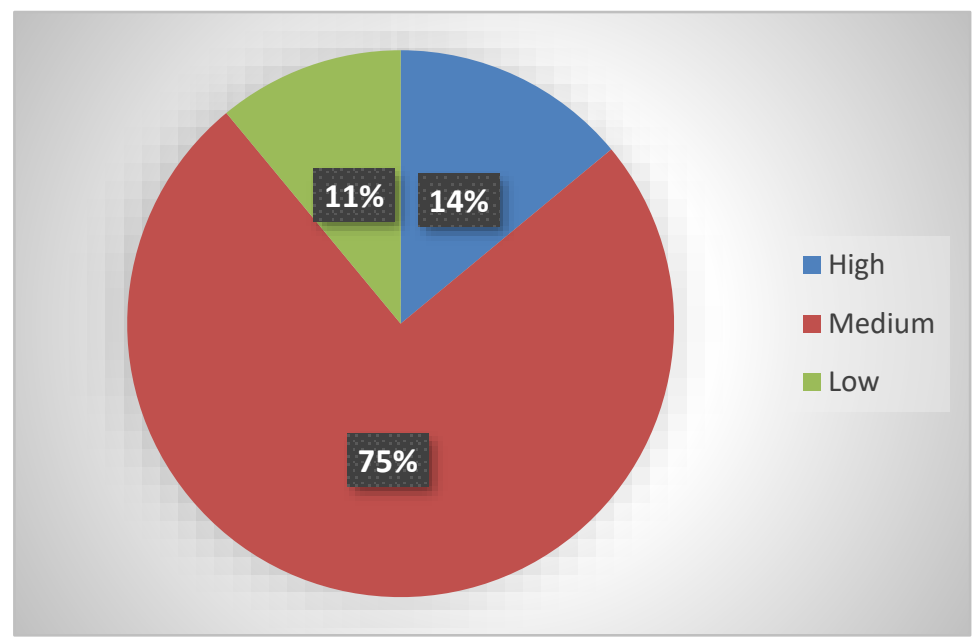

Figure 1. Independence Profile Graph 
Based on Table 1, it is obtained that the research subjects who will be given intervention in the experimental group are $(\mathrm{N}=20)$ people who have a low level of independence. The profile of the student's level of independence before the treatment was obtained from the results of the independence instrument given before the treatment was carried out. The independence instrument at this stage serves to reveal the profile or initial condition of the student's level of independence. This data will then be taken into consideration to see how much student independence increases between before and after being given online classical guidance services based on character values. The following are the results of the pre-treatment questionnaire.

Table 2. Experimental Group Before being given treatment

\begin{tabular}{cccc}
\hline No. & Subject & Pretest Score & Category \\
\hline 1 & VF & 55 & Low \\
2 & MRA & 53 & Low \\
3 & GP & 51 & Low \\
4 & DPN & 80 & Low \\
5 & FYP & 80 & Low \\
6 & SS & 80 & Low \\
7 & FNA & 80 & Low \\
8 & NMK & 77 & Low \\
9 & AGP & 80 & Low \\
10 & EYN & 75 & Low \\
11 & TAA & 77 & Low \\
12 & IDO & 76 & Low \\
13 & DYL & 80 & Low \\
14 & DMR & 80 & Low \\
15 & AS & 78 & Low \\
16 & RN & 80 & Low \\
17 & ADS & 65 & Low \\
18 & BAP & 73 & Low \\
19 & AII & 80 & Low \\
20 & ANF & 79 & Low \\
\hline
\end{tabular}

Character Value-Based Online Classical Guidance to Improve Student Independence.

Based on the results of the Wilcoxon Signed Rank Test, the results in the output table below are table 3 and table 4 as follows.

Tabel 3 Wilcoxon Test Output

\begin{tabular}{lrrr}
\hline & N & Mean Rank & Sum of Rank \\
\hline Negative Rank & 0 & .00 & .00 \\
\hline Positive Rank & 20 & 10.50 & 210.00 \\
\hline
\end{tabular}

Based on table 3, it can be seen that the negative rank values for the pretest and posttest scores of students' independence in overcoming the problem of the impact of COVID-19 showed that there were no subjects who experienced a decrease in the pretest score to the post-test score $(\mathrm{N}=0)$. Meanwhile, the positive rank, or the positive difference between the pretest and posttest scores of the level of independence, showed that all subjects $(\mathrm{N}=20)$ experienced an average increase of 10.50 . 
Tabel 4. The Result of Z-Score

\begin{tabular}{ccc}
\hline Mean Rank & $\mathbf{Z}$ & $\boldsymbol{p}$ \\
\hline 10.50 & -3.923 & 0.000 \\
\hline
\end{tabular}

Based on table 4 above, the results of the Wilcoxon Signed Rank Test test output that the value $(\mathrm{p}=0.000)<0.05$ so it can be concluded that there is a significant difference in the pretest and post-test scores on the level of student independence in overcoming the problem of the impact of COVID-19 after being given treatment for value-based online classical guidance services character.

Table 5. Student Independence Post Test Scores Overcoming the Impact of COVID-19 Posttreatment

\begin{tabular}{cccc}
\hline No. & Subject & Posttest Score & Category \\
\hline 1 & VF & 120 & Medium \\
2 & MRA & 125 & High \\
3 & GP & 130 & High \\
4 & DPN & 131 & High \\
5 & FYP & 126 & High \\
6 & SS & 119 & Medium \\
7 & FNA & 128 & High \\
8 & NMK & 130 & High \\
9 & AGP & 129 & High \\
10 & EYN & 133 & High \\
11 & TAA & 135 & High \\
12 & IDO & 129 & High \\
13 & DYL & 117 & Medium \\
14 & DMR & 119 & Medium \\
815 & AS & 125 & High \\
16 & RN & 110 & Medium \\
17 & ADS & 127 & High \\
18 & BAP & 119 & Medium \\
19 & AII & 131 & High \\
20 & ANF & 132 & High \\
\hline
\end{tabular}

It can be interpreted that the implementation of the treatment proves that the ideally implemented online classical guidance based on character values can increase student independence. Based on table 5, it can be seen that the score has increased when compared to the pretest score (see table 2), with an average of 126 which is in the high category. This is also supported by the active participation of students as research subjects who tell their experiences about the importance of growing independence, especially in overcoming the problem of the impact of covid 19. Because independence is one of the psychological and social capitals of students to overcome problems. 


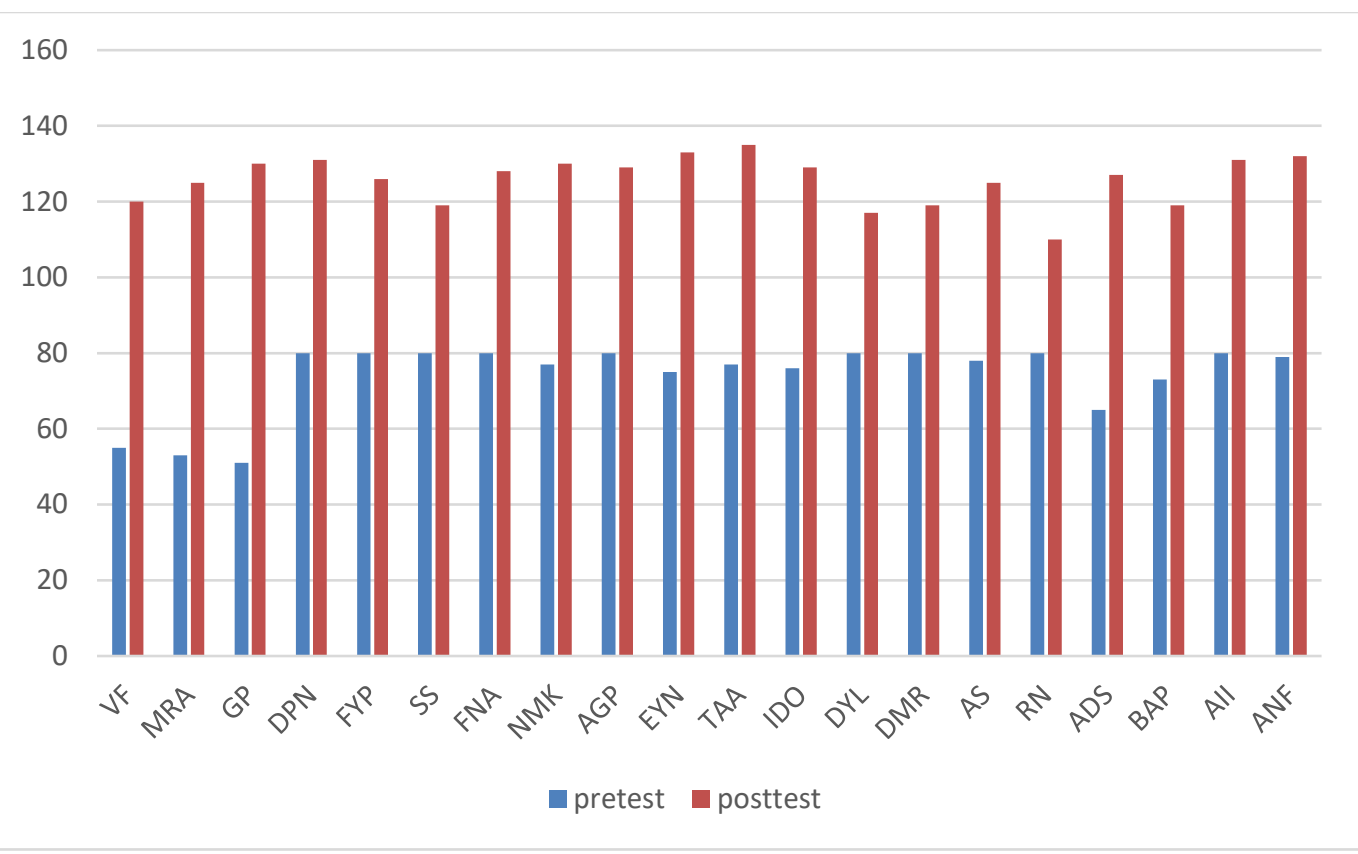

Figure 2. Histogram Comparison of Pretest Posttest Scores

Based on graph 1 above, it can be interpreted that there is an increase in the level of student independence as indicated by the post-test score which is greater than the pre-test.

\section{Discussion}

Independence is one of the important character values for students as it is the capital to achieve life goals that some students do not have. Independence as psychic capital includes high motivation, toughness in meeting difficulties, patience in solving problems, and being religiously able to accept the results of problem-solving. Independence as social capital in the form of communication skills, cooperation, discipline, and responsibility. Independence can take the form of motivation. Independent motivation is a type of motivation that leads to a better quality of learning, creativity, better performance, persistence, resilience, well-being, and motivation for lifelong learning (Kusurkar, 2019). As psychic capital, independence is closely related to psychological well-being, which includes personal growth, life goals, self-acceptance, environmental mastery, independence, and personal relationships with others (Neufeld \& Malin, 2019).

Independence needs to be formed and produced by oneself according to one's needs and circumstances, not solely because of external influences. Evaluation of independence character values needs to be developed and implemented thoroughly in the learning process from the design stage to implementation so that it is expected to have a positive impact on student development both in terms of learning achievement and nationalism attitudes. (Widiana et al., 2021). The use of instruments provides new confidence for educators that adolescent independence competencies need to be proven, healing, and good patient outcomes (Dewan \& Norcini, 2018). At this age, independence is very important to note because it is related to the way of life of adolescents, namely the achievement of the ability to make wise decisions and be able to direct themselves to face problems. Integration of current issues in education requires an emphasis on dialogical classroom practice that includes students' views along with multiple sources of knowledge and diverse perspectives on dealing with various problems. (Bossér \& Lindahl, 2019). Research shows that students who are given groupcounseling interventions with assertive training techniques help restore students' awareness of their right to have a happy and honorable life. (Rusmana et al., 2020). The main challenge is that the 
majority of students feel comfortable with learning approaches using applications on mobile phones that make them confident in the technology. (Hegarty \& Thompson, 2019).

Student independence can be formed and maintained through intra-campus and extra-campus activities. Through these activities, students can develop decision-making skills (Juan et al., 2018). Commitment to work adopted by adolescents is influenced by the balance achieved in the development of independence (Lases et al., 2018).

Independent students are able to use the opportunities that exist positively and productively. The fact is that there are still many students who have not been able to take advantage of opportunities properly. Independence involves a sense of will, agency, and initiative that does not preclude feelings of dependence on others (Kluwer et al., 2020). An independence orientation, or stable pattern of selfregulation, is theorized as a protective factor for long-term mental and physical health (Weinstein et al., 2019). Psychological well-being and self-regulation are the effects of independence (Lases et al., 2018).

Independent students have knowledge and experience, as well as a good mentality, but there are still mentally weak students. This needs to be supported by the provision of appropriate education and learning. One of them is through classical guidance services with a creative atmosphere. Creative learning, better progress, more helpful feedback, and greater student independence (Madjid et al., 2021). The need for students to be given opportunities to develop self-confidence and self-confidence is key to developing graduates who have the independence they need to succeed in the workplace. (Escolar-Llamazares et al., 2019; Henri et al., 2018). One of them, students who have an entrepreneurial mentality with the hope of workforce independence can be developed to adopt an entrepreneurial-oriented teaching model so that they have an overview of the structure of the business sector when they complete their studies. (Echeverri-Sanchez et al., 2018). It will be valuable for community-based work through hands-on practicum (Barber et al., 2018). Other factors to support independence include support from family, friends, and school, which are also related to the decline in academic procrastination supported by religious character (Madjid et al., 2021). More creative learning delivery, better progress, more helpful feedback, and greater student independence (Bubb \& Jones, 2020; Masalimova et al., 2019).

Findings are showing that students share experiences in their journals about the support from their parents to motivate them to carry out independent behavior. In addition, the parent factor also needs to support independence from an early age (Baudat, 2020; Hughes et al., 2018). With parental support for independence, adolescents will be more psychologically prosperous and skilled (Costa et al., 2019).

Through the implementation of online class guidance, students can develop dynamics so that they can affect all aspects of their lives, especially increasing independence. The role of classical guidance in higher education should not be maximized. Universities play a broad role in providing students with the opportunities and support needed to produce various types of knowledge that will be of benefit to them (Jabbar et al., 2018). Therefore, it is necessary to maximize the provision of continuous and structured classical guidance. Classical guidance functions as a basic service provided through group guidance services, and classical as a counselor's step to identify student needs and achieve student development tasks (Mulawarman et al., 2020). Implementation in a cooperative setting can help in reaching students and offering them the opportunity to interact with a digital-based classroom setting (Barnes, 2020; Mukuka et al., 2019; Wang et al., 2020). Class services can be carried out online so that they are more efficient and take into account that social, communication and technical competencies have a significant positive effect on student readiness (Al-adwan \& Khdour, 2020).

Some factors support increasing student independence, one of which is the role of researchers as motivators who can optimize student life skills, not only for themselves but also for research subjects in every stage of online classical guidance service based on character values. This means that 
character values are optimally integrated at every stage of service so that students can practice them in everyday life without bothering others. The material that became the topic of discussion was about independence in overcoming life problems by following the level of needs of students in general and group members in particular. Educators can encourage students' independence through the provision of flexible media in terms of time and place so that students are interested in reviewing learning later (Arista et al., 2018).

The implementation of classical guidance in this study was carried out for eight meetings, which were divided into three main activities, namely the initial stage, the core stage, and the final stage. The focus of giving treatment is achieving a level of independence based on aspects of independence, which include emotional independence, behavioral independence, and value independence. At the end of each session, students were asked to reflect by writing in a daily journal. In addition, homework assignments are given so that what is obtained in the online classical tutoring service session can be applied to everyday life. Students are asked to share their experiences related to the development of the value of independence in everyday life.

The achievement of the level of independence can be seen from the students' reflection journals after receiving online classical guidance services based on character values. The advantage of online classical guidance services based on character values lies in their implementation, which is effective in conveying material to many students so that time and energy can be effectively used in achieving goals.

The independence of students in overcoming the problem of the impact of COVID-19 is still low. This is evidenced by an increase in the number of students seeking assistance from the technical guidance and counseling service unit. Researchers as activity planners must be able to provide appropriate treatment according to the topic of discussion and the characteristics of students who are research subjects. Teenagers are more concerned about government restrictions designed to contain the spread of the virus, than the virus itself, and those concerns are linked to increased anxiety, insomnia, depressive symptoms, and decreased life satisfaction. (Kürşat et al., 2020; Magson et al., 2021; Shammi, 2021). The skills and competencies of independent students need to be developed as an innovative step in dealing with certain risks (Kvon et al., 2018). Especially in the development of mental health due to the impact of the COVID-19 pandemic (Filho et al., 2020; Ravšelj \& Tomaževi 2020). Because the impact of the COVID-19 pandemic is also on educational and social aspects as well as limited mobility (Chaturvedi et al., 2021; Kapasia et al., 2020; Saha et al., 2020). Another skill to deal with the impact of COVID-19, one of which is resilience, which is strengthened by religious character (Madjid et al., 2021).

The role of character values in shaping the student's personality has not been maximized. Discipline is the primary social control in the individual, as well as the primary means of managing one's self (Al-adwan \& Khdour, 2020; Iveson \& Maalsen, 2019). Positive energy can be formed from the existence of discipline, so discipline is a necessary mentality (Chen \& Wang, 2020; Holeman et al., 2020; Li, 2019). The provision of online classical guidance services based on the values of this discipline also has an accompanying impact during the implementation process. Giving motivation to students to be more disciplined through the habit of being responsible (Leyton-rom et al., 2021). The role of this responsible character can shape adolescents into independent individuals who can face the risks of their life choices. Responsibility is the result of independence (Beyer et al., 2017; Robinson et al., 2017). Responsibility is an obligatory act of taking care of something (Sand, 2021).

In addition to the impact on the level of student independence, other characteristics that need to be developed by students are religious, namely how students believe and carry out worship according to their religion. The religious character has an important role in shaping student independence, namely strengthening the belief that Allah SWT does not burden a person but according to his abilities. Verily, with hardship comes ease. The religious character contains the principles of life (Ives \& Kidwell, 2019). These principles are held by individuals to be fully believed. Discipline character 
serves as a form of student attitude to respecting time. Self-management has to do with self-discipline (Pelletier et al., 2017). The character of responsibility forms the attitude of students who dare to accept the results of problem-solving. Because responsibility is part of moral character (Anderson et al., 2021). There is a positive relationship between the character of discipline and religious character (Tahir et al., 2019). The more religious, the more disciplined a person will be to behave according to the religious norms that are believed.

The interaction process between lecturers and students during online classical guidance services provides effective communication that can encourage students' psychological well-being to convey problems during discussion sessions. The post-test results, which were classified as significantly increased, could not be separated from each stage of the process of implementing the implementation of online classroom guidance services based on character values which were followed by students. The active role of students in understanding the material and conducting discussions affects all aspects of their lives, especially in terms of independence in solving the problems of the impact of COVID19.

Furthermore, in addition to the importance of higher education institutions in forming the character of students, the role of the family, especially parents, also has a major and important role. The family as the main educator in fostering the character of independence can develop the potential of students. The existence of a good cooperative relationship between the role of guidance and counseling services in universities and parents of students is very helpful in optimizing the achievement of student independence and overcoming the problem of the impact of COVID-19.

This study has limitations related to the scope of the subjects studied, namely only within the scope of the university and tested in one experimental group. In addition, other factors that can increase independence, such as family support or differences in gender and age, also need to be revealed in further research.

\section{CONCLUSION}

Classical online guidance based on character values can increase student independence in solving personal, social, academic, and career problems as the impact of COVID-19. The implications of research results have a positive impact on the implementation of guidance and counseling carried out by the Guidance and Counseling Technical Implementation Unit at the university to improve student psychology.

Suggestions for further research are to develop and identify other problems related to student independence so that the results of this study serve as a reference for need assessment for the development of guidance and counseling programs in universities. There is a finding that family factors affect the level of independence, so further research is needed on the development of familybased guidance and counseling models to support the achievement of independence development tasks for students.

\section{REFERENCES}

Al-adwan, A. S., \& Khdour, N. (2020). Exploring student readiness to mooc s in j ordan : A structural equation modelling. 19, 223-242.

Anderson, R. A., Kamtekar, R., Nichols, S., \& Pizarro, D. A. (2021). "False positive" emotions, responsibility , and moral character. Cognition, 214(May), 104770. https://doi.org/10.1016/j.cognition.2021.104770

Arista, F. S., Education, P., Program, P., Kuswanto, H., Education, P., \& Program, P. (2018). Virtual physics laboratory application based on the android smartphone to improve learning independence and conceptual understanding. 11(1), 1-16.

Barber, S., Brettell, R., Perera-Salazar, R., Greenhalgh, T., \& Harrington, R. (2018). UK medical 
students' attitudes towards their future careers and general practice: a cross-sectional survey and qualitative analysis of an Oxford cohort. BMC Medical Education, 18(1), 160. https://doi.org/10.1186/s12909-018-1197-z

Barnes, S. J. (2020). International journal of information management information management research and practice in the post-covid-19 world. International Journal of Information Management, 55(June), 102175. https://doi.org/10.1016/j.ijinfomgt.2020.102175

Baudat, S. (2020). Parental solicitation and adolescents 'information management: the moderating role of autonomy-supportive parenting. Journal of Child and Family Studies, 426-441. https://doi.org/10.1007/s10826-019-01687-Z

Beyer, F., Sidarus, N., Bonicalzi, S., \& Haggard, P. (2017). Beyond self-serving bias : diffusion of responsibility reduces the sense of agency and outcome monitoring. December 2016, 138-145. https://doi.org/10.1093/scan/nsw160

Bossér, U., \& Lindahl, M. (2019). Students' positioning in the classroom: a study of teacher-student interactions in a socioscientific issue context. Research in Science Education, 49(2), 371-390. https://doi.org/10.1007/s11165-017-9627-1

Bubb, S., \& Jones, M. A. (2020). Learning from the COVID-19 home-schooling experience: Listening to pupils, parents/carers, and teachers. Improving Schools, 23(3), 209-222. https://doi.org/10.1177/1365480220958797

Chanana, N., \& Sangeeta. (2020). Employee engagement practices during COVID-19 lockdown. Journal of Public Affairs, August, 1-8. https://doi.org/10.1002/pa.2508

Chaturvedi, K., Vishwakarma, D. K., \& Singh, N. (2021). Children and youth services review covid19 and its impact on education, social life and mental health of students : A survey. Children $\begin{array}{llll}\text { and Youth } \quad \text { Services } & \text { Review, } & \text { 2020), }\end{array}$ https://doi.org/10.1016/j.childyouth.2020.105866

Chen, Z., \& Wang, C. Y. (2020). The discipline of happiness: The foucauldian use of the "positive energy" discourse in China's ideological works. https://doi.org/10.1177/1868102619899409

Cohen, L. (2007). Research methods in education. In Research Methods in Education. https://doi.org/10.4324/9780203029053

Costa, S., Gugliandolo, M. C., Barberis, N., Cuzzocrea, F., \& Liga, F. (2019). Antecedents and consequences of parental psychological control and autonomy support: The role of psychological basic needs. Journal of Social and Personal Relationships, 36(4), 1168-1189.

Dewan, M., \& Norcini, J. (2018). A purpose-driven fourth year of medical school. Academic Medicine, 93(4), 581-585. https://doi.org/10.1097/ACM.0000000000001949

Echeverri-Sanchez, L., Valencia-Arias, A., Benjumea-Arias, M., \& Barrera-Del Toro, A. (2018). Factores que inciden en la intención emprendedora del estudiantado universitario: Un análisis cualitativo. Revista Electrónica Educare, 22(2), 1. https://doi.org/10.15359/ree.22-2.10

Escolar-Llamazares, M., Luis-Rico, I., de la Torre-Cruz, T., Herrero, Á., Jiménez, A., PalmeroCámara, C., \& Jiménez-Eguizábal, A. (2019). The Socio-educational, Psychological and Family-Related Antecedents of Entrepreneurial Intentions among Spanish Youth. Sustainability, 11(5), 1252. https://doi.org/10.3390/su11051252

Filho, W. L., Brandli, L. L., Salvia, A. L., Rayman-bacchus, L., \& Platje, J. (2020). COVID-19 and the UN sustainable development goals : Threat to solidarity or an opportunity? 1-14.

Ganciu, M., \& Ganciu, O.-M. (2014). Development of the creative capacity by means of aerobic dance in higher deadlock education. Procedia - Social and Behavioral Sciences, 163, 110-114. https://doi.org/10.1016/j.sbspro.2014.12.294

Gonzaga-López, C., Buchmann, F. M., Dautermann, T., \& Ludwig, T. (2020). Implementing precision approaches supported by satellite-based augmentation systems in the Austrian Alps. Journal of Air Transportation, 28(3), 70-81. https://doi.org/10.2514/1.D0155

Hegarty, B., \& Thompson, M. (2019). A teacher's influence on student engagement: using 
smartphones for creating vocational assessment eportfolios. Journal of Information Technology Education: Research, 18, 113-159. https://doi.org/10.28945/4244

Henri, D. C., Morrell, L. J., \& Scott, G. W. (2018). Student perceptions of their autonomy at University. Higher Education, 75(3), 507-516. https://doi.org/10.1007/s10734-017-0152-y

Holeman, I., Kane, D., \& Holeman, I. (2020). Information technology for development humancentered design for global health equity human-centered design for global health equity. https://doi.org/10.1080/02681102.2019.1667289

Hughes, C., Lindberg, A., \& Devine, R. T. (2018). Autonomy support in toddlerhood: similarities and contrasts between mothers and fathers. 32(7), 915-925.

Ives, C. D., \& Kidwell, J. (2019). Religion and social values for sustainability. Sustainability Science, 14(5), 1355-1362. https://doi.org/10.1007/s11625-019-00657-0

Iveson, K., \& Maalsen, S. (2019). Social control in the networked city: Datafied dividuals, disciplined individuals and powers of assembly. https://doi.org/10.1177/0263775818812084

Jabbar, A., Analoui, B., Kong, K., \& Mirza, M. (2018). Consumerisation in UK higher education business schools: Higher fees, greater stress and debatable outcomes. 85-100. https://doi.org/10.1007/s10734-017-0196-z

Joia, L. A. (2021). Zoom In, Zoom Out: The Impact of the COVID-19 Pandemic in the Classroom.

Juan, P. A., Zacarés, J., \& Ferreres, A. (2018). Emotional separation, autonomy in decision-making, and psychosocial adjustment in adolescence : A proposed typology. Journal of Child and Family Studies, 1373-1383. https://doi.org/10.1007/s10826-017-0980-5

Kapasia, N., Paul, P., Roy, A., Saha, J., Zaveri, A., \& Mallick, R. (2020). Children and youth services review impact of lockdown on learning status of undergraduate and postgraduate students during COVID-19 pandemic in West Bengal, India. Children and Youth Services Review, 116(June), 105194. https://doi.org/10.1016/j.childyouth.2020.105194

Kim, J. S., Gu, M. O., \& Chang, H. (2019). Effects of an evidence-based practice education program using multifaceted interventions: A quasi-experimental study with undergraduate nursing students 13 Education 1303 Specialist Studies in Education 11 Medical and Health Sciences 1110 Nursing. BMC Medical Education, 19(1), 1-10. https://doi.org/https://doi.org/10.1186/s12909-019-1501-6

Kizilcec, F., \& Mar, P. (2017). Computers \& Education Self-regulated learning strategies predict learner behavior and goal attainment in Massive Open Online Courses Ren e. 104, 18-33. https://doi.org/10.1016/j.compedu.2016.10.001

Kluwer, E. S., Karremans, J. C., Riedijk, L., \& Knee, C. R. (2020). Autonomy in Relatedness : How Need Fulfillment Interacts in Close Relationships. https://doi.org/10.1177/0146167219867964

Kürşat, M., Servet, Ş., Gülay, A., \& Aytül, Ş. (2020). Prevalence of depression, anxiety, distress and insomnia and related factors in healthcare workers during COVID - 19 pandemic in Turkey. Journal of Community Health, 45(6), 1168-1177. https://doi.org/10.1007/s10900-020-00921-w

Kusurkar, R. A. (2019). Autonomous motivation in medical education. Medical Teacher, 41(9), 1083-1084. https://doi.org/10.1080/0142159X.2018.1545087

Kvon, G. M., Vaks, V. B., Masalimova, A. R., Kryukova, N. I., Rod, Y. S., Shagieva, R. V., \& Khudzhatov, M. B. (2018). Risk in implementing new electronic management systems at universities. Eurasia Journal of Mathematics, Science and Technology Education, 14(3), 891902. https://doi.org/10.12973/ejmste/81060

Lases, S. S., Slootweg, I. A., \& Erik, E. G. J. M. P. (2018). Efforts, rewards and professional autonomy determine residents ' experienced well - being. Advances in Health Sciences Education, 23(5), 977-993. https://doi.org/10.1007/s10459-018-9843-0

Leyton-rom, M., Jos, J., \& Batista, M. (2021). Predictive model for amotivation and discipline in physical education students based on teaching - learning styles. 1-14.

Li, L. (2019). Politics of anticorruption in China : Paradigm Change of the party's disciplinary regime 
politics of anticorruption in China : Paradigm Change of the. Journal of Contemporary China, 28(115), 47-63. https://doi.org/10.1080/10670564.2018.1497911

Madjid, A., Sutoyo, D. A., \& Shodiq, S. F. (2021). Academic procrastination among students: The influence of social support and resilience mediated by religious character. Cakrawala Pendidikan, 40(1), 56-69. https://doi.org/10.21831/cp.v40i1.34641

Magson, N. R., Freeman, J. Y. A., Rapee, R. M., Richardson, C. E., Oar, E. L., \& Fardouly, J. (2021). Risk and protective factors for prospective changes in adolescent mental health during the COVID-19 pandemic. Journal of Youth and Adolescence, 50(1), 44-57. https://doi.org/10.1007/s10964-020-01332-9

Masalimova, A. R., Mikhaylovsky, M. N., Grinenko, A. V, \& Smirnova, M. E. (2019). The interrelation between cognitive styles and copying strategies among student youth. 15(4), 1-7.

Mukuka, A., Mutarutinya, V., \& Balimuttajjo, S. (2019). Exploring the barriers to effective cooperative learning implementation in school Mathematics classrooms. 7864.

Mulawarman, M., Susilawati, S., Syifa, L., \& Rifani, E. (2020). Classroom guidance strategy with flipped method in guidance and counseling services at indonesia schools in the digital era. Islamic Guidance and Counseling Journal, 3(2), 61-74. https://doi.org/10.25217/igcj.v3i2.646

Neufeld, A., \& Malin, G. (2019). Exploring the relationship between medical student basic psychological need satisfaction, resilience, and well-being : a quantitative study. 9, 1-8.

Pamungkas, J., \& Yogyakarta, U. N. (2021). Cypriot Journal of Educational Character value that formed through learning the art of playing GACIL in early childhood. 16(4), 1503-1516.

Pei, L., \& Wu, H. (2019). Does online learning work better than offline learning in undergraduate medical education? A systematic review and meta-analysis. Medical Education Online, 00(00). https://doi.org/10.1080/10872981.2019.1666538

Pelletier, L., Shanmugasegaram, S., Patten, S. B., \& Demers, A. (2017). Self-management of mood and / or anxiety disorders through physical activity / exercise. 37(5), 149-159.

Poza-Vilches, F., López-Alcarria, A., \& Mazuecos-Ciarra, N. (2019). A professional competences' diagnosis in education for sustainability: A case study from the standpoint of the Education Guidance Service (EGS) in the Spanish context. sustainability, 11(6), 1568. https://doi.org/10.3390/su11061568

Ravšelj, D., \& Tomaževi־, N. (2020). Impacts of the COVID-19 pandemic on life of higher education students : A global perspective. January, 1-34.

Robinson, K. H., Smith, E., Davies, C., Robinson, K. H., Smith, E., \& Responsibilities, C. D. (2017). Responsibilities, tensions and ways forward: parents ' perspectives on children's sexuality education. Sex Education, 1811, 1-15. https://doi.org/10.1080/14681811.2017.1301904

Rusmana, N., Hafina, A., Siddik, R. R., \& Nur, L. (2020). Self-esteem development of vocational high school students in Indonesia: Does group counseling with assertive training technique help? Cakrawala Pendidikan, 39(3), 573-582. https://doi.org/10.21831/cp.v39i3.31363

Saha, J., Barman, B., \& Chouhan, P. (2020). Children and youth services review lockdown for COVID-19 and its impact on community mobility in India: An analysis of the COVID-19 Community Mobility Reports , 2020. Children and Youth Services Review, 116(June), 105160. https://doi.org/10.1016/j.childyouth.2020.105160

Sand, M. (2021). Varieties of responsibility : two problems of responsible. Synthese, 198(s19), 47694787. https://doi.org/10.1007/s11229-018-01951-7

Setiyowati, A. (2019). 4 1,3,4. 38(1), 45-62. https://doi.org/10.21831/cp.v38i1.21509

Shammi, M. (2021). Strategic assessment of COVID - 19 pandemic in Bangladesh : comparative lockdown scenario analysis, public perception. 6148-6191. https://doi.org/10.1007/s10668020-00867-y

Sitorus. (2019). Character value to improve students ' learning outcomes and. 38(1), 120-129. https://doi.org/10.21831/cp.v38i1.20878 
Tahir, M., Amiruddin, R., Palutturi, S., Rivai, F., \& Saleh, L. M. (2019). Religius character in improving primary health services quality in South Sulawesi. 10(7).

Wang, H., Charoenmuang, M., Knobloch, N. A., \& Tormoehlen, R. L. (2020). Defining interdisciplinary collaboration based on high school teachers' beliefs and practices of STEM integration using a complex designed system. 4.

Wara, E., Aloka, P. J. O., \& Odongo, B. C. (2018). Relationship between emotional engagement and academic achievement among Kenyan secondary school students. Academic Journal of Interdisciplinary Studies, 7(1), 107-118. https://doi.org/10.2478/ajis-2018-0011

Weinstein, N., Legate, N., Ryan, W. S., \& Hemmy, L. (2019). Autonomous orientation predicts longevity: New findings from the nun study. January 2018, 181-193. https://doi.org/10.1111/jopy.12379

Widiana, I. W., Tegeh, I. M., \& Artanayasa, I. W. (2021). The project-based assessment learning model that impacts learning achievement and nationalism attitudes. Cakrawala Pendidikan, 40(2), 389-401. https://doi.org/10.21831/cp.v40i2.38427 